\title{
Exploring the challenges of pepper smallholder farmers in Sarawak: a qualitative study
}

\author{
${ }^{1}$ Mazlan, M.N., ${ }^{1, *}$ Saili, A.R., ${ }^{2}$ Saili, J., ${ }^{3}$ Zulkefli, F., ${ }^{3}$ Syahlan, S. and ${ }^{3}$ Ruslan, N.A. \\ ${ }^{1}$ Faculty of Plantation and Agrotechnology, Universiti Teknologi Mara, Jalan Meranek, Kota \\ Samarahan 93400 Malaysia \\ ${ }^{2}$ Faculty of Cognitive Sciences and Human Development, Universiti Malaysia Sarawak, Jalan Datuk \\ Mohammad Musa, Kota Samarahan 93400 Malaysia \\ ${ }^{3}$ Faculty of Plantation and Agrotechnology, Universiti Teknologi Mara Jasin, Kg. Sri Mendapat Merlimau \\ 77300 Malaysia
}

\section{Article history: \\ December 2020 \\ Available Online: 20 \\ December 2020 \\ Keywords: \\ Pepper farmers, \\ Smallholders, \\ Challenges, \\ Farmers, \\ Climate}

Received: 23 July 2020

Received in revised form: 1

Accepted: 10 December 2020

DOI:

https://doi.org/10.26656/fr.2017.4(S5).019

\section{Introduction}

Pepper or the scientific name Piper nigrum L. is one of the oldest known spices in the international market. The large-scale cultivation of pepper in Malaysia began in Sarawak in 1876 when the Chinese migrants were allowed to take up large acreage of land for large production of pepper (Olalere et al., 2016). The pepper plant is still a popular choice of crop among smallholders in Malaysia and is known to be an important source of side income for local people especially in some parts of Sarawak such as Kuching, Samarahan, Serian, Sri Aman, Betong, and Sarikei who actively cultivate the pepper crop. Sarawak is known as a major producer in Malaysia which covers 17,134 ha area in 2018 (Malaysian Pepper Board, 2018). The commodity price of pepper is the significant determinant of the total revenue of Malaysia particularly for the state of Sarawak and pepper growers as pepper farming is the only source of livelihood for a majority of the pepper growers in the state. Pepper farming is not only regarded as a source of side income, but it is also considered as a traditional practice that has been passed down for generations by the local people.
However, it is not easy to cultivate the pepper plant in order to obtain a good and high-quality product because pepper is usually planted by smallholder farmers primarily in infertile hill slopes (Kamarulzaman et al., 2013). Thus, this study investigates the issue and explores the potential challenges faced by pepper growers.

Pepper is one of the important cash crops supporting the livelihood of about 67,000 rural dwellers in upland areas of Sarawak and about $95 \%$ of the pepper traded globally is in the form of black and white peppercorns and the remaining $5 \%$ is made up of pepper oleoresin, pepper oil, green pepper, and ground pepper (DOA, 2020). Up until recently, Sarawak is still the main producer of black and white pepper in Malaysia, which is about 23,780 tonnes of black pepper and 6,794 tonnes of white pepper in 2018 (Malaysia's Open Data Portal, 2019). It is estimated that $90 \%$ of pepper production is destined for export markets. The target markets of the pepper industry include China, the Middle East, Japan, Australia, Europe, and South Africa. The pepper production pattern in 1980-2012 indicates an increasing 
trend albeit at a very slow growth rate and cyclical behaviour like other agricultural commodities in Malaysia. In accordance with National Commodity Policy (2011-2020), the Malaysian government targets at expending the pepper cultivated area from the current 16,331 ha to 20,110 ha by the year 2020 . Based on a planting density of 2,000 vines/ha, there will be an urgent need of 7.588 million cuttings for the next five years in order to achieve this target.

Nelson (2014) stated that pepper is mainly grown in the remote areas of Sarawak, mostly by the rural poor smallholders, where there is limited access to information and other facilities regarding the agricultural practices and marketing process. Additionally, most of the farmers are golden agers as these are usually those who remain in rural areas. Therefore, it appears that implicit assumption by policymakers and development practitioners that older farmers, when considered at all are less productive, more risk-averse and less innovative than younger ones (Heide-Ottosen et al., 2014). According to Wong et al. (2010), most of the farmers are smallholders, thus affecting the amount of pepper production to smaller volumes. Therefore, the major problems and constraints faced by the pepper farmers are escalating cost for managing disease and pest problems, increasing cost of fertiliser, pesticides and labour inputs and also fluctuating export market prices (DOA, 2020).

Furthermore, the climate change has brought a new generation of pests and pathogens apart from causing erosion to native gene banks which has made it essential to gear up and set priorities to meet the challenges through Sustainable Production (Kandiannan, 2014). The pepper industry is expected to increase rapidly over the next decades. However, production is expected to grow slowly because of low productivity and price volatility (Abdulla et al., 2015). Moreover, price is the most important factor that contributes to the reduction in pepper production, thus creating a situation for farmers to switch to other lucrative cash crops such as palm oil and rubber (Nelson, 2014). Not only does the total revenue of Malaysia, particularly for the state of Sarawak, is influenced by the up and down of pepper export earnings resulting from the highly unstable pepper prices, but the high volatility of international pepper price is also undoubtedly the most detrimental factor to pepper farmers as pepper farming is the sole source of livelihood for the majority of pepper farmers in Sarawak (Wong et al., 2010).

\section{Materials and methods}

The informants were recruited continuously during the research, in accordance with the snowball principle.
This method of sampling is a nonprobability sampling technique in which the subjects of existing study recruit future subjects from among their associates who share similar interests. The samples of this research involve 6 participants of self-employed pepper growers between the ages of 40 to 60 years old. In-depth interview sessions were conducted to explore several aspects such as feelings, emotions, experienced, life history, and other relevant details related to the research purposes. The data from the interviews were transcribed and thematic analysis was performed. Thematic analysis is the process of identifying patterns or themes within qualitative data (Maguire and Delahunt, 2017). This involves the process of coding the overall data that led to identifying and reviewing the key themes. The process of creating codes can be described as both data reduction and data complication (Yow, 2004). Each theme was inspected to having an insight into participants' perceptions and motivations. Subsequently, the initial theme is generated and then reviewed for the purpose of defining and naming the main themes and sub-themes.

\section{Results}

The analysis of qualitative data has revealed that all six participants expressed that they have faced more than one challenges. The main themes include a shortage of workers, climates, profit, government assistance, and pest and disease.

\subsection{Theme 1: Shortage of workers}

Majority of the participants highlighted that lack of sufficient workers especially in the farm operation could affect the management of the farm. One of the participants expressed that he does not have sufficient labour in order to facilitate him in the farm activities especially in the early planting stages:

"When we started working our farm, it was only my wife and me who did all the clearing work. Due to lack of manpower in the farm, it took a long time to finish certain tasks such as transplanting, fertilizing or pruning, and also harvesting". (Farmer 1)

Another participant described what he felt personally when it comes to the early planting process due to lack of labour:

"It was very exhausting in the early stages of working on the farm because my farm covers a large area of our land. Sometimes, I get help from my father, but he could not stay long due to age factor. Now, the farm rests on my responsibility as my father has passed away.". (Farmer 2) 
Another participant stated that the early planting stage had consumed so much time because he was doing it all by himself in addition to the location of his farm that was far from his residence.

"Most of the work in the farm that involves clearing the area, cutting the trees, and lifting the heavy fertiliser sacks are carried out by me as I have no employee and no one in the family can assist me. Also, the farm is located quite far from my house which takes me about an hour of walking to get there.". (Farmer 3)

One participant shared his experience with the current situation about the lack of workers that affects his farm operation.

"My father-in-law used to help me a long time ago during the first stage of pepper establishment. He taught and helped me on how to plant the pepper. Now I am the only one who takes care of the farm and it is more difficult during the harvesting.". (Farmer 4)

Farmer 5 added that he went through a lot of hardship due to shortage of workers as he could not afford to hire any worker.

"I first started planting pepper in 1971. I've gone through all the hardship of working the farm. This was caused by lack of labour as it was only me who did all the work. Although sometimes my wife lends a helping hand, I still could not cope with so many work on the farm. I could not afford to hire people due to the low prices of pepper". (Farmer 5)

Farmer 6 echoed what was mentioned by Farmer 5 that it takes time to do the tasks due to insufficient workers and at the same time he had to focus on cultivating other types of crop.

"Even though my wife used to help me at the pepper farm, she would not be able to do so during the paddy harvesting season. Therefore, some farming work may take longer time to be finished because it was only me who working the pepper crop". (Farmer 6)

\subsection{Theme 2: Climates}

All the participants agreed upon the issue of unavoidable climate change. Climate situations such as rainy season or prolong dried season can affect the farm operation and thus causing problems to the plant and yield performance.

One participant spoke that the weather does give effect to his pepper plant and daily routine in his farm:

"Yes, it does affect us, especially when prolonged rainy and dried seasons occur. When it happens, it's difficult to conduct maintenance activity during the rainy seasons such as spraying and manuring the plant that can easily be infected with crop diseases. Then, during dried seasons the leaves tend to become yellowish". (Farmer 1)

Other participants admitted that the rainy season affects the yield quality such as the fruits and crop diseases which tend to attack the plant. Furthermore, the soil quality is also affected due to the unfavourable climate:

"The plants tend to produce less peppercorn because during rainy seasons the peppercorns are easily rotten and would fall off. The quality of peppercorn is also reduced". (Farmer 3)

"The climate gives some impact, especially in the rainy season. If I'm late in harvesting the peppercorn, it will immediately become rotten. Same as drought season which causes difficulties for me because I can't use the fertilizer. The leaves quickly turn yellowish, the soil surface hardened and cracks lead to problems such as the infestation of ants. Prolonged rainy days also can lead to soil erosion". (Farmer 4)

"Normally, the leaves turn yellowish during prolonged dried season. It looks unhealthy. But if it's always raining, the soil becomes wet and pepper vines can die quite easily. However, pepper vines planted in the hilly areas, peppercorn can fell off easily during the rainy season". (Farmer 5)

"Usually, the often-rainy weather is not good. The fungal disease would tend to attack. If it is drought season, the problem is commonly related to the soil". (Farmer 6)

\subsection{Theme 3: Profit}

The entirety of the participants acknowledged that low current market prices of pepper produce (black pepper) have affected their total income. One participant told that his income from the pepper cultivation was affected due to the low-price market trend in recent years:

"From my experience, income from pepper production is not enough. Nowadays the prices for black pepper are considered low compared to a few years before. The current prices now are about RM 7 to RM 9 per kilogram compared to about RM 30 per kilogram a few years back. Also, the current prices for white pepper now are about RM 10". (Farmer 1)

Next, two participants mentioned that their net income of pepper production was considered low after 
considering other operating costs such as fertilisers, pesticide, and herbicide. Therefore, they cannot afford to hire workers:

"The annual income that I gain from farming is about RM2000 to RM3000 only. With that amount, I had to buy fertilisers, pesticide, and herbicide. Overall, the amount is barely enough to sustain the entire operation of the farm and my expenses. That's why I'm not able to hire workers". (Farmer 2)

"Roughly I can get around RM2000 per year, it is not even enough to hire workers". (Farmer 4)

He also mentioned that he had experienced on selling the black pepper at very low prices:

"Now the price has dropped drastically. I had the experience of selling black pepper at very low prices which was at RM 2.30 per kilogram as compared to the highest price many years ago which was RM 30". (Farmer 4)

Another participant also expressed that the current low market price was not enough to support earning for his family. He also added that he had experienced in selling black pepper during a decent market price in previous years.

"Nowadays, the price is low, but years before, it was decent. The profit that I earned from my farm was not enough for me and my family nowadays. Once allocated for the fertilizer and pesticide, the balance is barely enough to cover other expenses. I believe that I will be able to gain profit again when the market price is higher than how much it is today. For instance, RM 28, RM 29, and RM 30 per kilogram. Now the current price is around RM 6 to RM 7 per kilogram which is surely not enough". (Farmer 3)

Similarly, Farmer 5 expressed that it has been a long time since the last increase of commodity price of the pepper in the market:

"The current price is not favourable now. Thus, it has affected our incomes greatly. Also, I could not remember there was a time that the pepper price went up. Maybe four or five years ago". (Farmer 5)

The last participant felt that the uncertainty of market price had led to insufficient income and told that during the high prices of pepper, he could afford to buy a permanent support system for his pepper plants which was considered as expensive:

"... if it can cover the cost of fertiliser and other chemical products, that is good enough. As far as I can remember, there was one time when I sold the pepper at
RM 31 per kilogram. It was that time also that I could afford to buy 'Belian' wood posts due to good sales revenue". (Farmer 6)

\subsection{Theme 4: Government assistance}

All participants claimed that the assistance provided by the government was not enough and inefficiently distributed. The forms of assistance provided by the government can be in terms of the monetary scheme, fertilizer scheme, farming tools, equipment scheme, conducting guideline courses for pepper farming and other aids which deemed necessary for helping pepper growers. One participant claimed that the aids he received from the government were barely enough to support his pepper farming because it was given as a one -off only. Furthermore, according to the participant, sufficient aids should enable him to focus on his pepper farming thus produce a better yield.

"The farming authority came to my village during the 'Hari Peladang' and visited my farm. From such visit, I received a one-off scheme that includes the fertilizer, herbicide and seedlings. However, the aids provided by the authority was not enough. It is important for me to receive an appropriate amount of aids so that I can focus on the crop production thus producing better yield". (Farmer 1)

The next two participants stated that they never had a chance to join any guideline courses on pepper planting let alone receiving any schemes introduced by the government. Moreover, one of them was left in the dark when he knew that other farmers had received some form of government aids which excluded him:

"I have received no assistance at all since I started pepper cultivation, not even any guideline courses. However, even though not receiving any assistance from the authority, I keep on farming and producing black peppers. Who knows if the prices will go up in the near future?" (Farmer 6).

"I have not received any form of aid from the authority. Also, I learned about pepper cultivation from some friends in which we often have several discussion sessions about anything related to pepper cultivation such as problems associated with our pepper farm. We feel that we are among the unfortunate farmers who have never received any form of aid from the authorities despite having several other farmers that we know, receiving them. So far, I'm all independent and all expenses are covered by me". (Farmer 2)

He also added that he never enrolled in any course on pepper-related subjects: 
"Never, just a few of us were selected to join the course". (Farmer 4)

However, another farmer said that he was lucky to join the course regarding pepper management and reiterated further that he has never received any government assistance despite applying several times for such schemes.

"I have joined the pepper course once in Kuching for one week. It was about crop diseases, type of new varieties, and the maintenance of pepper but it never mentioned about any schemes. I only got the fertilizer scheme and never got any other schemes even though I had applied a few times. Some of my friends who applied have already received the assistance". (Farmer 5)

\subsection{Theme 5: Pest and Disease}

All participants acknowledged that there were pest and disease infestations that occurred in their farms. One of the participants who had experienced it first-hand, expressed his fear towards the pest and disease:

"I'm afraid of insect and disease infestation especially the fungal disease (foot rot), smelly bug (tingid bugs) and mealybug. Among them, the most severe infestation is caused by foot rot. It attacks the vines and destroys the whole pepper plant. The leaves turn yellowish and the root will be rotten. It can also spread to the nearby pepper plant." (Farmer 1)

Another participant shared his feeling of losing several pepper vines that were infected by a type of plant disease which attack the roots and provided a description about the pattern of the infection:

"There is a common disease that attacks my pepper vines which is root disease. I don't know how to treat it properly. What saddened me was that it affected more than 20 pepper vines on my farm which has cost me quite a lot. (Farmer 2)

Moreover, other participants spoke about the frequency of pest and disease infestation and its symptoms. One of them also added about the difficulties of detecting early signs of the disease and ensuring what kind of disease it was.

"The fungal diseases that attack some of my pepper vines display a whitish appearance on the root area. Bugs also often attack the leaves especially if they are not controlled with pesticide. Lately, the presence of these bugs is abundant in the farm". (Farmer 3)

"Some of the pepper vines in my farm were affected by the foot rot disease, especially in the root area. I dug and checked the root; it was already rotten. Then I realized it was too late to save the plant. Also, upon inspecting other pepper vines nearby the infected ones, they were all infected by the same disease. This is based on the colour of the leaves that have turned yellowish". (Farmer 4)

"The infestation has caused some 200 planting stands in the farm to be rotten, in which I had 500 stands at the start of the planting. Also, the peppercorn also turns blackish because of the disease". (Farmer 5)

"The affected roots mostly showed whitish symptom. Right after pulling off the plant from the ground to reveal the roots, I could see that the root is rotten and smelly, and the plant is no longer producing yields". (Farmer 6)

\section{Discussion}

The qualitative data has shed some light on the challenges in pepper cultivation which include a shortage of workers, climate, profit, government assistance, and pest and disease. All participants in this study manage their farm by themselves from the beginning of cultivation and experienced hardship to do all farming activities due to lack of workers to facilitate them which has also affected their production. Many researchers have acknowledged that a farmer's performance is affected by human capital (Anderson and Feder, 2003). As mentioned by Taylor and Charlton (2019), labour supply risks are paramount during harvesting time and an important potential component of risk is the lack of available labour at the times and places needed to harvest crops. All participants also agreed that lack of manpower has extended the duration of completing many activities involved in the early stage of establishing their farms. These findings concur with Satishkumar and Umesh (2018) who stated that there are different kinds of implications associated with agricultural labour scarcity such as delay in crop establishment, no or untimely weeding, irrational use of fertilizers, insufficient irrigation to crops, and poor crop growth.

Climate is uncontrollable which has since become the concern of many farmers. Climate change is evident, and it is a great challenge for the scientific community to find solutions to mitigate its ill-effect (Kandiannan, 2014). Some participants agreed that rainy seasons and drought season have led to pest and disease infestation such as fungal diseases and ant infestation as mentioned by the participants in this study. Hence one of them said about the soil erosion that happened during rainy seasons and cracks during drought. In a past study by Kandiannan (2014), climate change also would bring new pests and pathogens apart from causing erosion to native gene banks and it is essential to gear up and set priorities to meet these challenges. Apart from drought, 
the conditions for agriculture are also becoming increasingly difficult due to the gradual rise in temperature, salinization and changing rainy seasons (Lüthi, 2019). When the climate impacts the plant and soil, that also means it affects the yield such as the peppercorn, sources of black and white pepper.

Profit had been illustrated by the participants as low and not enough due to the unfavourable market price compared with recent years. The current trend of low market prices generally affects the income of farmers. Malaysians being the fifth largest producer of pepper has experienced a decline in the price and economic value of the product (Olalere et al., 2016). Pepper farming has changed the life of the people in the rural areas of the state for the better over the past 10 years, but the drastic drop in the price of commodity off late has affected their livelihood (Bernama, 2018). Price is the most important factor that contributes to the reduction in pepper area and pepper production, thus creating a situation for farmers to switch to other lucrative cash crops such as palm oil and rubber (Nelson, 2014). It is such a difficult situation when the smallholders do not get compatible profit due to the low price of pepper per kilogram hence their products are not much.

Most participants perceived that the assistance provided by the authority was less effective despite several continuous efforts provided in the form of schemes to assist the farmers. Although the assistance provided in terms of subsidies was perceived as beneficial for farmers in short-term, it has a drawback in its overall effectiveness. Agricultural input subsidies such as fertilizers and pesticides are allocated based on the land size owned by farmers. Therefore, it offers more benefits to the farmers with larger farm size (Kari, 2018), although smallholders received a considerable amount of benefits from the subsidies. Most participants indicated that they have received subsidy assistance from the authority at least once, whereas a minority of them informed that they have not received any. Also, those who have not received such assistance were keen to know the factors contributing to the matter, that may allow for improvement. Hence, it can be implied that the assistance in terms of fertilizer scheme, pesticide scheme, and the monetary scheme is beneficial for a short-term solution but have yet to meet a long-term solution.

Crop loss due to pest and disease incidence has been identified as one of the major production constraints (Thangaselvabal et al., 2008). Most of the participants mentioned the issues related to crop diseases as opposed to pest attack in their farms. According to Hua (2002), disease problems are major constraints in the cultivation of pepper in all pepper producing countries and Malaysia is no exception especially in Sarawak, where pepper vines are affected by a myriad of diseases; some of these are devastatingly causing heavy crop losses or plant death while others are less severe with minor economic significance.

Due to the challenges and difficulties faced by pepper growers in the industry, relevant government agencies should take a step forward in providing various forms of effective assistance. The assistance by relevant government agencies in the forms of various aid schemes should be distributed via proper mechanisms to ensure that every individual farmer in the industry receives such aids. Farmers should also be guided and given extensive training especially those who are new in the pepper cultivation to enable them to be self-sufficient and less dependent on government assistance. Furthermore, the government needs to be consistent in its effort to reduce the burden of farmers especially in terms of operational cost. Our country is known as one of the countries producing top quality peppers but is still facing uncertainty on the market prices of the product which is beyond our grasp even though we are among the major exporters of the product. As the price reflects the income of poor smallholder, it can be the motivating factor for the farmers. Competitive price ensures the continued development of smallholder pepper growers, thus reducing the production gap between the smallholder and big company. Lastly, considering the pest and diseases issues faced by the farmers, it is hopeful that the relevant government agencies such as DOA and MPB that have shown relentless efforts on the matter to enhance their efforts or work hand by hand in addressing such issues.

\section{Conclusion}

Based on the findings of this study, it can be concluded that small-scale pepper growers in the country, especially Sarawak are currently facing several challenges. Therefore, analysing and identifying the challenges that they are currently facing may provide the opportunity to improve the future of pepper farming. Moreover, the government plays an important role to ensure the survival of the pepper cultivation industry especially in Sarawak which is known as the top producer in Malaysia. Due to the challenges and difficulties faced by pepper growers in the industry, relevant government agencies should take a step forward in providing various forms of effective assistance. The assistance by relevant government agencies in the forms of various aid schemes should be distributed via proper mechanisms to ensure that every individual farmer in the industry receives such aids. Farmers also should be guided and given extensive training especially those who are new in the pepper cultivation to enable them being 
self-sufficient and less dependent on government assistance. Furthermore, the government needs to be consistent in its effort to reduce the burden of farmers especially in terms of operational cost. Our country is known as one of the countries producing top quality peppers but is still facing uncertainty on the market prices of the product which is beyond our grasp even though we are among the major exporters of the product. As the price reflects the income of poor smallholders, it can be the motivating factor for the farmers. Competitive price ensures the continued development of smallholder pepper growers, thus reducing the production gap between the smallholder and big company. Lastly, considering the pest and diseases issues faced by the farmers, it is hopeful that the responsible government agencies that have shown relentless efforts on the matter to enhance their efforts in addressing such issues.

\section{Conflict of interest}

The authors declare no conflict of interest.

\section{Acknowledgments}

The authors would like to acknowledge the support from Sumitomo Foundation Japan and Universiti Teknologi MARA (UiTM) Sarawak Campus.

\section{References}

Abdulla, I., Arshad, F.M., Tasrif, M., Bach, N.L. and Mohammadi, S. (2015). A systems approach to study the Malaysian pepper industry. American Journal of Applied Sciences, 12(7), 487-494. https:// doi.org/10.3844/ajassp.2015.487.494

Anderson, J.R. and Feder, G. (2003). Rural Extension Services - The World Bank Agricultural and Rural Development Department. Policy Research Working Paper. World Bank Group e-book. https:// doi.org/10.1596/1813-9450-2976

Bernama. (2018). Sarawakian farmers struggle with low pepper prices. Retrieved January 10, 2020, from Bernama website: http://www.bernama.com/statenews/berita.php?id $=1669601$

DOA. (2020). Official Website of Department Of Agriculture Sarawak. Retrieved January 10, 2020, from Department of Agriculture website: https:// doa.sarawak.gov.my/page-0-0-138-Pepper.html

Heide-Ottosen, S., Vorbohle, T. and O’Neill, K. (2014). The ageing of rural populations: evidence on older farmers in low- and middle-income countries. London: HelpAge International.

Hua, W.M. (2002). Fungal diseases of black pepper and their management in Sarawak, Malaysia. Presented at Symposium on Pests and Diseases on Pepper, 30th International Pepper Community Session and Other Meetings, (Part 1), p. 36-45. Sarawak, Malaysia.

Kamarulzaman, N.H., Mohd, H.H., Mohayidin, G. and Enchi, J. (2013). Buyers' Preferences Among Pepper Farmers in Sarawak. Journal of Agribusiness Marketing, 6, 1-13.

Kandiannan, K. (2014). Climate Change and black pepper production. Indian Journal of Arecanut, Spices and Medical Plants, 16(4), 31-37.

Kari, F. (2018). Evaluation of Agricultural Subsidies and the Welfare of Rice farmers. Malaysian Agricultural Subsidies Report 2018. Kuala Lumpur: Institute of Democracy and Economic Affairs (IDEAS) Policy Research Berhad.

Lüthi, P. (2019). Climate change: Complex challenges for agriculture. Retrieved January 10, 2020, from The Financial Express website: https:// thefinancialexpress.com.bd/public/index.php/views/ reviews/climate-change-complex-challenges-foragriculture-1547047376

Maguire, M. and Delahunt, B. (2017). Doing a Thematic Analysis: A Practical, Step-by-Step Guide for Learning and Teaching Scholars. All Ireland Journal of Teaching and Learning in Higher Education, 9(3), 335.

Nelson, F.Y.K. (2014). Analysis of Malaysian Pepper Market Model. Sarawak, Malaysia: Universiti Malaysia Sarawak, MSc. Thesis.

Olalere, O.A., Nour, A., Alara, O.R. and Ahmad, M.M. (2016). The Impact of Pepper Production on Malaysian Economy and the Need for Nutraceutical Diversification The Impact of Pepper Production on Malaysian Economic and the Need for Nutraceutical Diversification, presenteda at The National Conference for Postgraduate Research 2016, p. 453457. Malaysia: Universiti Malaysia Pahang.

Satishkumar, M. and Umesh, K.B. (2018). Farmers Strategies to Cope Labour Shortage in Northern and Southern Dry Zones of Karnataka, India. Current Agriculture Research Journal, 6(2), 206-212. https://doi.org/10.12944/carj.6.2.10

Taylor, J.E. and Charlton, D. (Eds.) (2019). The Farm Labor Problem: A Global Perspective. USA: Academic Press. https://doi.org/10.1016/C2018-000292-3

Thangaselvabal, T., Justin, C.G.L. and Leelamathi, M. (2008). Black pepper (Piper Nigrum L.) 'The King of spices' - A review. Agricultural Reviews, 29, 8998.

Wong, S.K., Abdul Rahim, K. and Nasir Shamsudin, M. (2010). Long-run Determinants of Export Supply of 
Sarawak Black and White Pepper: An ARDL Approach. Global Economy and Finance Journal, 3 (1), 78-87.

Yow, V. (2004). Review of Key Themes in Qualitative Research: Continuities and Change by Paul Atkinson, Amanda Coffey, and Sara Delamont. Oral History Review, 3(1), 104-106. https:// doi.org/10.1525/ohr.2004.31.1.104 